\title{
Cea
}

JURNAL PENDIDIKAN GEOGRAFI

\section{TINGKAT KESEJAHTERAAN BURUH SADAP KARET PTPN VIII WANGUNREJA DI KECAMATAN DAWUAN KABUPATEN SUBANG}

\author{
Kanah $^{1}$, Epon Ningrum ${ }^{2}$, Bagja Waluya ${ }^{3}$ \\ Departemen Pendidikan Geografi, FPIPS, UPI, \\ email : jae_waluya@upi.edu
}

\begin{abstract}
ABSTRAK
Pendapatan buruh sadap karet di perkebunan PTPN VIII Wangunreja, Kecamatan Dawuan Subang, masih minim di bawah UMR. Pendapatan seseorang sangat berpengaruh pada tingkat kesejahteraan, selain factor lainnya. Tujuan penelitian ini untuk mengetahui tingkat kesejahteraan buruh sadap karet berdasarkan indikator BPS tahun 2005. Metode penelitian yang digunakan adalah metode deskriptif. Populasi penelitiannya adalah seluruh masyarakat buruh sadap karet di PTPN VIII Wangunreja Kecamatan Dawuan. Sampel pada penelitian ini berjumlah 60 orang, yakni wara 1 (24 orang), wara 2 (6 orang), dan wara 3 (30 orang). Variabel penelitian terdiri dari variabel bebas (pendapatan, pengeluaran keluarga, keadaan tempat tinggal, fasilitas tempat tinggal, kesehatan anggota keluarga, kemudahan mendapatkan pelayanan kesehatan, kemudahan menyekolahkan anak dan kemudahan mendapatkan fasilitas transportasi), dan variabel terikatnya tingkat kesejahteraan. Analisis data penelitian ini menggunakan persentase dan skoring. Hasil penelitian menunjukan bahwa buruh sadap karet memiliki pendapatan yang rendah sedangkan pengeluarannya tinggi, buruh sadap karet sebagian besar tinggal di rumah yang permanen dengan fasilitas yang kurang lengkap, tingkat kesehatan buruh sadap karet termasuk kategori baik karena mereka mudah mendapatkan pelayanan kesehatan, buruh sadap karet cukup mudah dalam menyekolahkan anak dan kesulitan dalam mendapatkan fasilitas transportasi. Berdasarkan indikator kesejahteraan menurut BPS tahun 2005 sebagian besar buruh sadap karet di Kecamatan Dawuan termasuk dalam tingkat kesejahteraan sedang, sebanyak 78,3\% dan sebagian lagi termasuk dalam tingkat kesejahteraan rendah sebanyak 15\%, dan tingkat kesejahteraan tinggi sebanyak 6,7\%.
\end{abstract}

Kata kunci : perkebunan, kesejahteraan, buruh sadap karet.

\section{PENDAHULUAN}

Perkebunan merupakan salah satu sub sektor strategis yang secara ekonomis, ekologis dan sosial budaya mempunyai peranan penting dalam pembangunan nasional. Sesuai Undang-Undang No. 18 tahun 2004, Tentang Perkebunan, pembangunan perkebunan bertujuan untuk meningkatkan pendapatan masyarakat; meningkatkan penerimaan negara dan devisa negara; menyediakan lapangan kerja, meningkatkan produktivitas, nilai tambah dan daya saing; memenuhi kebutuhan konsumsi dan bahan baku industri dalam negeri; dan mengopti- malkan pengelolaan sumber daya alam secara berkelanjutan. (Kementerian Pertanian, 2012).

Karet merupakan komoditi ekspor yang cukup berperan dalam perekonomian nasional di Indonesia. Baik sebagai penghasil devisa penduduk ataupun sebagai lapangan kerja bagi penduduk. Diperkirakan sepuluh juta penduduk terlibat dalam lapangan usaha karet di Indonesia. Perkebunan karet diusahakan oleh perkebunan-perkebunan besar seperti PNP/PTP, perusahaan swasta nasional dan asing serta sebagian besar diusahakan oleh petani kecil serta tradisional. Luas areal 
perkebunan karet di Indonesia ditaksir 2,4 juta hektar yang terdiri dari perkebunan seluas 0,5 juta hektar dan karet rakyat seluas 1,9 juta hektar. Produksi karet di Indonesia sekitar $70 \%$ dihasilkan oleh perkebunan rakyat. Sedangkan sisanya berasal dari perkebunan besar, baik perkebunan negara, swasta asing maupun swasta nasional. (Sastraatmadja, 1984).

Kecamatan Dawuan merupakan salah satu lokasi sebaran perkebunan karet milik PTPN VIII. Perusahaan yang berada di Kecamatan ini adalah PTPN VIII Wangunreja yang mengelola hasil perkebunan karet dengan luas 1.222,97 Ha. Berdasarkan data induk pegawai PTPN VIII Wangunreja jumlah buruh sadap karet secara keseluruhan sebanyak 259 orang sedangkan buruh sadap karet yang berada di Kecamatan Dawuan berjumlah 152 orang.

Menyadap karet di PTPN VIII Wangun-reja merupakan pekerjaan utama yang dijadikan mata pencaharian bagi sebagian masyarakat yang ada di Kecamatan Dawuan, mata pencaharian tersebut dilakukan untuk memenuhi kebutuhan hidup keluarga. Masing-masing buruh sadap memiliki jumlah pohon sadapan kurang lebih 300 pohon dengan perolehan upah masih di bawah Upah Minimum Kabupaten (UMK).

Masalah kesejahteraan selalu berhubungan dengan pemenuhan kebutuhan, masyarakat buruh sadap karet dikatakan sejahtera apabila mereka mampu memenuhi kebutuhan hidupnya, seperti yang telah dijelaskan Kementrian Koordinator Kesejahteraan dalam Rinawati (2010), sejahtera yaitu suatu kondisi masyarakat yang terpenuhi kebutuhan dasarnya. Kebutuhan dasar tersebut berupa kecukupan dan mutu sandang, pangan, papan, kesehatan, pendidikan, lapangan pekerjaan, dan kebutuhan dasar lainnya seperti lingkungan yang bersih, aman, dan nyaman.

Tingkat kesejahteraan masyarakat buruh sadap karet PTPN VIII Wangunreja Kecamatan Dawuan, diukur berdasarkan beberapa indikator. Indikator tersebut digunakan untuk memberikan gambaran mengenai aspek sosial maupun ekonomi masyarakat buruh sadap.

Aktivitas penyadapan karet sudah terjadi dalam waktu yang lama, tetapi pendapatan yang diperoleh masyarakat buruh sadap masih berada di bawah UMR Kabupaten Subang sedangkan kebutuhan hidup semakin meningkat. Tingkat kesejahteraan masyarakat buruh sadap karet PTPN VIII Wangunreja di Kecamatan Dawuan diukur berdasarkan beberapa indikator, Indikator tersebut digunakan untuk memberikan gambaran mengenai aspek sosial maupun ekonomi masyarakat buruh sadap karet. Menurut Badan Pusat Statistik tahun 2005 indikator kesejahteraan terdiri atas pendapatan, pengeluaran keluarga, keadaan tempat tinggal, fasilitas tempat tinggal, kesehatan keluarga, kemudahan mendapatkan pelayanan kesehatan, menyekolahkan anak dan kemudahan mendapatkan fasilitas transportasi.

Tujuan penelitiannya adalah 1) mengidentifikasi tingkat pendapatan masyarakat buruh sadap karet; 2) mengidentifikasi tingkat pengeluaran masyarakat buruh sadap karet; 3) mengidentifikasi keadaan tempat tinggal masya-rakat buruh sadap karet; 4) mengidentifikasi fasilitas tempat tinggal masyarakat buruh sadap karet; 5) mengidentifikasi kesehatan masyarakat buruh sadap karet; 6) mengidentifikasi cara mendapatkan fasilitas kesehatan pada masya-rakat buruh sadap karet; 7) mengidentifikasi pendidikan anak pada masyarakat buruh sadap karet; 8) mengidentifikasi cara mendapatkan fasilitas transportasi pada masyarakat buruh sadap karet; dan 9) mengidentifikasi tingkat kesejah-teraan masyarakat buruh sadap karet di PTPN VIII Wangunreja di Kecamatan Dawuan Kabupaten Subang.

\section{METODE PENELITIAN}

Kecamatan Dawuan merupakan salah satu kecamatan yang berada di Kabupaten Subang dengan luas 7.568,39 Ha. 
Kecamatan Dawuan terdiri dari 10 desa yaitu Desa Jambelaer, Cisampih, Margasari, Situsari, Sukasari, Rawalele, Dawuan Kidul, Dawuan Kaler, Manyeti, Batusari.

Metode penelitian menggunakan metode deskriptif. Populasinya yaitu buruh sadap karet yang ada di Kecamatan Dawuan yang berjumlah 152, adapun lokasi penelitian dapat dilihat pada gambar 1. Pengambilan sampel dipilih dengan proportional random sampling dengan menggunakan rumus Slovin, berdasarkan perhitungan, diperoleh total sampel buruh sadap karet yang diambil dalam penelitian ini sebanyak 60 orang. Jumlah tersebut tersebar di 3 Wara yaitu Wara 1 sebanyak 24, Wara 2 sebanyak 6, Wara 3 sebanyak 30.
Variabel penelitian terdiri dari variabel bebas yaitu pendapatan, pengeluaran keluarga, keadaan tempat tinggal, fasilitas tempat tinggal, kesehatan anggota keluarga, kemudahan mendapatkan pelayanan kesehatan, menyekolahkan anak, dan kemudahan mendapatkan fasilitas transportasi, dan variabel terikat yaitu tingkat kesejahteraan. Instrumen penelitian menggunakan angket yang ditujukan kepada masyarakat buruh sadap karet di Kecamatan Dawuan sebanyak 60 orang. Tujuan menggunakan angket dalam penelitian ini agar memudahkan peneliti dalam pengkodean. Teknik analisis data menggunakan analisis deskriptif persentase dan skoring.

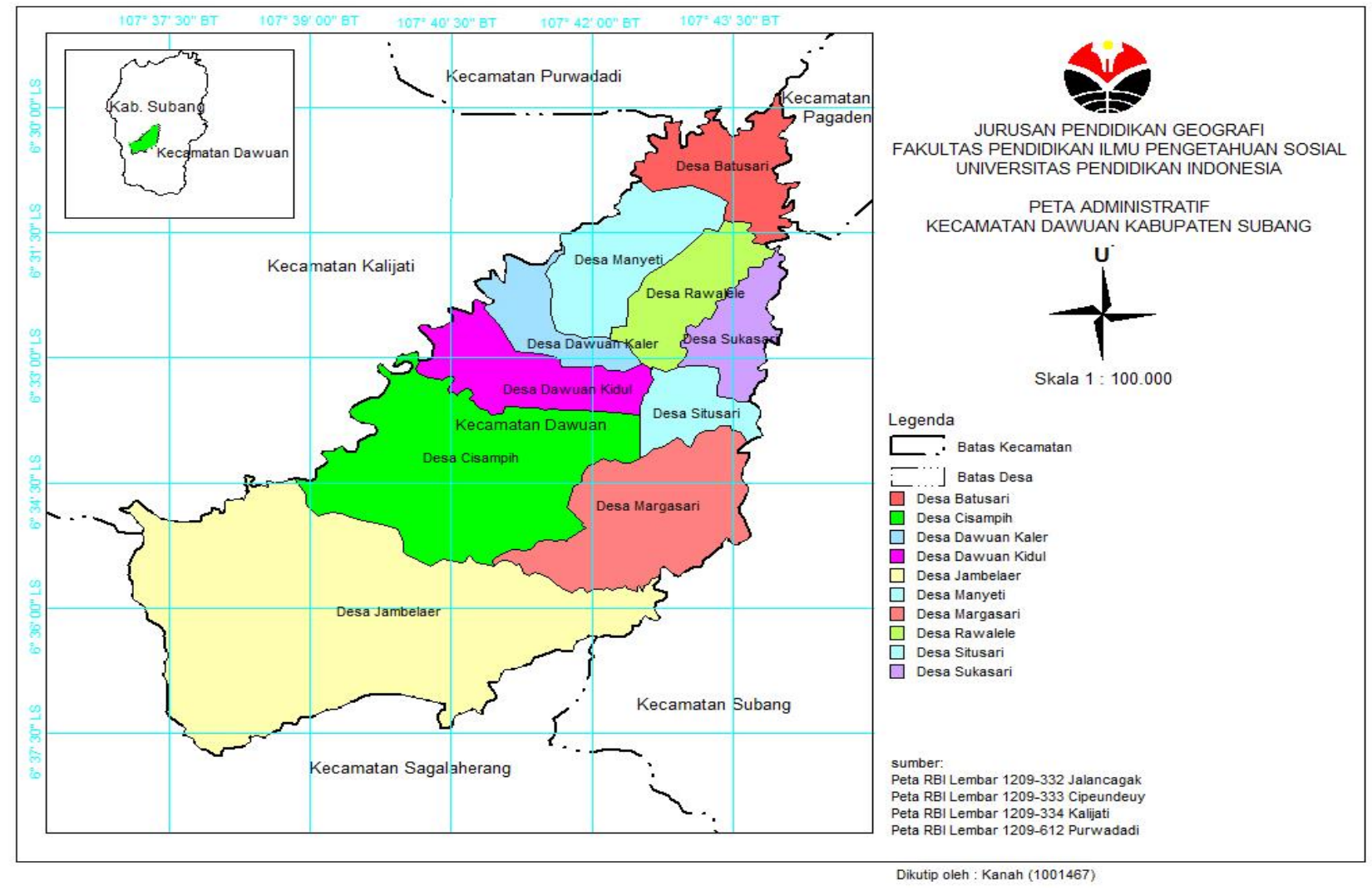

Gambar 1. Peta Kecamatan Dawuan

\section{HASIL DAN PEMBAHASAN}

Pertanian di Indonesia tidak hanya terdiri atas sub-sektor pertanian dan subsektor pangan, tetapi juga sub-sektor perkebunan, dan sub-sektor peternakan. Sub-sektor perkebunan merupakan subsektor pertanian yang secara tradisional merupakan salah satu penghasil devisa negara. Hasil-hasil perkebunan yang selama ini telah menjadi komoditas ekspor antara lain: karet, kelapa sawit, teh, kopi, dan tembakau. Sebagian besar tanaman perkebunan merupakan usaha perkebunan rakyat, sedangkan sisanya diusahan oleh perkebunan besar, baik milik pemerintah maupun swasta. (Menurut Soetrisno, 2002)

Keberadaan perkebunan karet diharapkan mampu memberikan perubahan 
pada tingkat kesejahteraan masyarakat buruh sadap seperti yang dijelaskan dalam UU RI No. 18 Tahun 2004, Tentang Perkebunan bahwa Perkebunan adalah segala kegiatan yang mengusahakan tanaman tertentu pada tanah dan/atau media tumbuh lainnya dalam ekosistem yang sesuai, mengolah dan memasarkan barang dan jasa hasil tanaman tersebut, dengan bantuan ilmu pengetahuan dan teknologi, permodalan serta manajemen untuk mewujudkan kesejahteraan bagi pelaku usaha perkebunan dan masyarakat.

Masyarakat dikatakan sejahtera apabila masyarakat tersebut dapat memenuhi kebutuhan dasarnya seperti yang dikemukakan Kementrian Koordinator Kesejahteraan Rakyat (dalam Rinawati, 2010) sejahtera yaitu suatu kondisi masyarakat yang terpenuhi kebutuhan dasarnya. Kebutuhan dasar tersebut berupa kecukupan dan mutu sandang, pangan, papan, kesehatan, pendidikan, lapangan pekerjaan, dan kebutuhan dasar lainnya seperti lingkungan yang bersih, aman, dan nyaman. Untuk mengetahui tingkat kesejahteraan masyarakat buruh sadap karet dapat dilihat dari indikator kesejahteraan berdasarkan Badan Pusat Statistik (2005) yang dibagi ke dalam delapan indikator yang meliputi pendapatan, pengeluaran keluarga, keadaan tempat tinggal, fasilitas tempat tinggal, kesehatan anggota keluarga, kemudahan mendapatkan pelayanan kesehatan, kemudahan menyekolahkan anak, dan kemudahan menda-patkan fasilitas transportasi.

Pendapatan merupakan salah satu indi-kator tingkat kesejahteraan, semakin tinggi pendapatan maka tingkat kesejahteraannya pun akan lebih baik. Perbedaan upah yang diterima buruh sadap karet di Kecamatan Dawuan tergantung pada golongan kerja yang dimiliki masingmasing buruh sadap karet. Golongan kerja tersebut diperoleh dari lamanya buruh sadap karet bekerja di PTPN VIII Wangunreja. Semakin lama buruh sadap karet bekerja di PTPN maka memungkinkan semakin tinggi pendapatan yang diperolehnya, karena setiap tahun para buruh tersebut akan memperoleh kenaikan strip golongan. Pendapatan buruh sadap karet dapat dilihat pada tabel 1.

Tabel 1. Tingkat Pendapatan

\begin{tabular}{ccccc}
\hline No & $\begin{array}{c}\text { Pendapatan } \\
\text { (Bulan) }\end{array}$ & \multicolumn{2}{c}{ Jumlah } \\
\cline { 3 - 5 } & $<\operatorname{Rp~500.000~}$ & $\mathrm{f}$ & $\%$ \\
\hline 2 & $\operatorname{Rp~} 500.000-\operatorname{Rp~} 1.000 .000$ & 21 & 0 \\
\hline 3 & $\operatorname{Rp~} 1.000 .001-\operatorname{Rp~} 1.500 .000$ & 31 & 35,3 \\
\hline 4 & $>\operatorname{Rp} 1.500 .000$ & 60 & 100 \\
\hline \multicolumn{2}{c}{ Jumlah }
\end{tabular}

Berdasarkan tabel 1, kurang dari setengahnya masyarakat buruh sadap karet mempunyai pendapatan Rp. 1.000 .000 - Rp. 1.500 .000 yaitu sebanyak $46,7 \%$, sedangkan pendapatan yang lebih dari Rp. 1.500.000 hanya $8,3 \%$. Pendapatan tersebut merupakan pendapatan yang diperoleh setiap bulannya dari hasil menyadap 350 pohon karet yang diberikan PTPN VIII Wangunreja kepada para buruh sadap.

Pendapatan merupakan salah satu indikator tingkat kesejahteraan buruh sadap karet, semakin tinggi pendapatan maka tingkat kesejahteraannya akan lebih baik. Seperti yang dikatakan Adisasmita (2013) bahwa pendapatan mencerminkan standar hidup riil masyarakat. Standar hidup riil masyarakat menunjukan tingkat kesejah-teraan masyarakat, maka dapat dikatakan bahwa pendapatan merupakan kriteria tingkat kesejahteraan masyarakat. Pendapatan utama masyarakat buruh sadap karet PTPN VIII Wangunreja tergolong rendah. Untuk memenuhi kebutuhannya, masyarakat ini memanfaatkan pendapatan lain dari hasil usaha 
yang mereka lakukan selain menjadi buruh sadap, selain itu juga sebagian mereka memberdayakan anggota keluarga yang lain seperti istri atau anak untuk bekerja agar dapat menambah penghasilan untuk memenuhi kebutuhan sehari-hari.
Besarnya pengeluaran suatu rumah tangga menggambarkan tingkat kesejahteraan yang bersangkutan. Semakin tinggi pengeluaran untuk kebutuhan non makan, menunjukan adanya peningkatan kesejahteraan rumah tangga tersebut (tabel 2).

Tabel 2. Tingkat Pengeluaran

\begin{tabular}{|c|c|c|c|}
\hline \multirow[t]{2}{*}{ No } & \multirow{2}{*}{$\begin{array}{l}\text { Pengeluaran } \\
\text { (Bulan) }\end{array}$} & \multicolumn{2}{|c|}{ Jumlah } \\
\hline & & $f$ & $\%$ \\
\hline 1 & $<\operatorname{Rp} 500.000$ & 0 & 0 \\
\hline 2 & Rp 500.000 - Rp 1.000.000 & 8 & 13,3 \\
\hline 3 & Rp 1.000.000 - Rp 1.500.000 & 21 & 35 \\
\hline 4 & $>\operatorname{Rp} 1.500 .000$ & 31 & 51,7 \\
\hline & Jumlah & 60 & 100 \\
\hline
\end{tabular}

Tabel 2, menunjukan bahwa lebih dari setengahnya masyarakat buruh sadap karet memiliki pengeluaran lebih dari Rp. 1.500 .000 per bulan yaitu sebanyak 51,7\% dan masyarakat yang mempunyai pengeluaran kurang dari Rp. 1.000.000 hanya 13,3\%. Jika dihubungkan dengan pendapatan utama, sebagian besar buruh sadap karet memiliki pengeluaran yang lebih tinggi dibandingkan dengan jumlah pendapatan yang diperoleh dari hasil menyadap karet di PTPN VIII Wangunreja.

Besarnya pengeluaran suatu rumah tangga menggambarkan tingkat kesejahteraan rumah tangga yang bersangkutan. Semakin tinggi pengeluaran yang dikeluarkan untuk kebutuhan non makan, menunjukkan adanya peningkatan kesejahteraan rumah tangga tersebut. Seperti di jelaskan Sukirno (2004) Pengeluaran/ konsumsi rumah tangga adalah nilai belanja yang dilakukan oleh rumah tangga untuk membeli berbagai jenis kebutuhanya. Pendapatan yang diterima suatu rumah tangga akan digunakan untuk membeli makanan, membiayai jasa angkutan, membayar pendidikan anak, membayar sewa rumah dan membeli kendaraan. Barang-barang tersebut dibeli rumah tangga untuk memenuhi kebutuhanya. Sebagian besar buruh sadap karet memiliki pengeluaran lebih dari Rp. 1.500.000, pengeluaran tersebut lebih tinggi dibandingkan dengan jumlah pendapatan yang diperoleh dari hasil menyadap. Pengeluaran tertinggi yang dikeluarkan para buruh sadap ini sebagian besar digunakan untuk makan sehari-hari.

Rumah merupakan salah satu aspek penting dalam kelangsungan hidup berumah tangga. Status kepemilikam rumah juga sangat penting karena akan mempengaruhi kenyaman dalam berumah tangga. Jenis bangunan terdapat tiga kategori pengklasifikasian jenis rumah yaitu permanen, semi permanen dan tidak permanen (Panggung). Perbedaan kategori jenis bangunan ini terlihat dari dinding dan lantai. Jenis bangunan dari rumah buruh sadap karet dapat dilihat dari tabel 3.

Tabel 3. Jenis Rumah

\begin{tabular}{clcc}
\hline \multirow{2}{*}{ No } & \multirow{2}{*}{ Jenis Rumah } & \multicolumn{2}{c}{ Jumlah } \\
\cline { 3 - 4 } & & $\mathrm{f}$ & $\%$ \\
\hline 1. & Tidak permanen & 0 & 0 \\
\hline 2. & Semi Permanen & 4 & 6,7 \\
\hline 3. & Permanen & 56 & 93,3 \\
\hline \multicolumn{2}{r}{ Jumlah } & 60 & 100 \\
\hline
\end{tabular}

Tabel 3, Menunjukan sebagian besar para buruh sadap karet menempati rumah dengan jenis bangunan permanen, rumah yang berdinding tembok dan lantainya dari 
keramik yaitu sebanyak 93\%. Rumah yang ditempati masyarakat buruh sadap karet ini rata-rata berukuran tidak terlalu besar, bahkan ada beberapa dari mereka menempati rumah dengan kondisi dinding dan keramik yang sudah retak-retak dan atap yang mulai keropos. Selain permanen sebagian kecil keluarga buruh sadap karet menempati rumah dengan jenis bangunan semi permanen, yaitu rumah yang setengah dindingnya terbuat dari tembok sebagian lagi terbuat dari anyaman bambu/bilik dan lantainya dari semen yaitu sebanyak 6,7\%.

Keadaan tempat tinggal atau rumah mencerminkan kondisi kesejahteraan seseorang, semakin baik tempat tinggalnya bisa dikatakan memiliki kesejahteraan yang baik pula. Seperti yang tercantum dalam Undang-Undang Republik Indonesia No. 1 (2011) Tentang Perumahan dan Kawasan Permukiman menjelaskan bahwa Rumah adalah bangunan gedung yang berfungsi sebagai tempat tinggal yang layak huni, sarana pembinaan keluarga, cerminan harkat dan martabat penghuninya, serta aset bagi pemiliknya. Di Kecamatan Dawuan sebagian besar para buruh sadap karet menempati rumah milik sendiri dengan jenis bangunan permanen yaitu rumah yang berdinding tembok dan lantainya dari keramik dan sebagian lagi tinggal bersama orang tuanya. Buruh sadap karet yang tinggal bersama orang tuanya karena mereka tidak memiliki biaya untuk membeli atau membangun rumah sendiri, pendapatan yang diperoleh hanya cukup digunakan untuk keperluan sehari-hari.

Selain kebutuhan sandang dan pangan, rumah merupakan salah satu kebutuhun pokok dalam kehidupan manusia. Berbagai fasilitas yang dapat mencerminkan tingkat kesejahteraan antara lain dapat dilihat dari kepemilikan pekarangan dan kelengkapan ruang. Untuk melihat kelengkapan fasilitas tempat tinggal tersebut dapat dilihat pada tabel 4 .

Tabel 4. Fasilitas Tempat Tinggal

\begin{tabular}{cllcc}
\hline \multirow{2}{*}{ No. } & \multirow{2}{*}{ Klasifikasi } & \multicolumn{2}{c}{ Jumlah } \\
\cline { 4 - 5 } & & 5 & f \\
\hline 1. & Lengkap & & 23 & 8,3 \\
\hline 2. & Cukup & & 32 & 53,4 \\
\hline 3. & Kurang & & 60 & 100 \\
\hline & & Jumlah &
\end{tabular}

Tabel 4, menunjukan lebih dari setengahnya masyarakat buruh sadap karet memiliki fasilitas tempat tinggal yang kurang lengkap yaitu sebanyak 53,3\% sedangkan masyarakat yang memiliki fasilitas yang lengkap hanya 8,3\%.

Fasilitas tempat tinggal merupakan sarana untuk melaksanakan segala aktivitas keluarga di rumah. Seperti yang tercantum pada Peraturan Menteri PU No.54 (1991) kebutuhan ruang per orang dihitung berdasarkan aktivitas dasar manusia di dalam rumah. Aktivitas seseorang tersebut meliputi aktivitas tidur, makan, kerja, duduk, mandi, kakus, cuci dan masak serta ruang gerak lainnya. Dilihat dari fasilitas tempat tinggal, lebih dari setengahnya masyarakat buruh sadap karet PTPN VIII Wangunreja memiliki fasilitas yang kurang lengkap. Setengah dari masyarakatnya tidak memiliki pekarangan, karena lahan yang mereka miliki terbatas dan hanya cukup untuk membangun satu rumah. Sebagian besar dari buruh sadap menggunakan satu ruangan tertentu untuk beberapa aktivitas seperti makan, nonton $\mathrm{tv}$ dan kumpul bersama keluarga, hal tersebut dilakukan karena keterbatasan ruangan.

Intensitas pemeriksaan kesehatan secara rutin memungkinkan anggota keluarga masyarakat buruh sadap untuk terhidar dari penyakit dan dapat hidup lebih sehat. Kesehatan merupakan salah satu kebutuhan manusia di samping kebutuhan lain, karena jika sehat dapat melakukan aktivitas dengan baik. Kondisi kesehatan merupakan indikator kesejahteraan dalam hal kualitas fisik (tabel 5). 
Tabel 5. Kesehatan Anggota Keluarga

\begin{tabular}{cllcc}
\hline \multirow{2}{*}{ No. } & \multirow{2}{*}{ Klasifikasi } & \multicolumn{2}{c}{ Jumlah } \\
\cline { 3 - 5 } & & f & $\%$ \\
\hline 1. & Bagus & & 0 & 0 \\
\hline 2. & Cukup & 46 & 73,3 \\
\hline 3. & Kurang & & 14 & 26,7 \\
\hline & & Jumlah & 60 & 100 \\
\hline
\end{tabular}

Tabel 5, menunjukan bahwa lebih dari setengahnya masyarakat buruh sadap karet memiliki tingkat kesehatan anggota keluarga yang cukup bagus sebanyak $73,3 \%$. Sebagian kecil dari masyarakat buruh sadap memiliki tingkat kesehatan anggota keluarga yang kurang bagus sebanyak $26,7 \%$.

Kesehatan merupakan salah satu aset terpenting untuk mendukung aktivitas yang dilakukan sehari-hari. Berdasarkan Undang-Undang Republik Indonesia No. 36 tahun 2009, tentang Kesehatan, Kesehatan adalah keadaan sehat, baik secara fisik, mental, spritual maupun sosial yang memungkinkan setiap orang untuk hidup produktif secara sosial dan ekonomis. Sebagian besar kesehatan anggota keluarga masyarakat buruh sadap karet sehat atau tidak memiliki memiliki penyakit dan sebagian lagi memiliki penyakit, adapun penyakit yang sering diderita masyarakat buruh sadap diataranya maag, sakit kepala, alergi, rheumatik dan darah tinggi. Kesadaraan akan pentingnya kesehatan pada masyarakat buruh sadap ini masih terbilang rendah hal tersebut dapat terlihat dari intensitas cek kesehatan, sebagian besar masyarakat buruh sadap karet tidak pernah melakukan pemeriksaan kesehatan, mereka lebih memilih membeli obat warung dan membiarkan penyakitnya karena merasa tidak terlalu parah.

Kemudahan medapatkan fasilitas kesehatan yang diberikan pihak PTPN VIII Wangunreja ini dilihat dari proses penanganan serta jarak tempuhnya (tabel 6).

Tabel 6. Kemudahan Mendapatkan Fasilitas Kesehatan

\begin{tabular}{clccc}
\hline No. & Klasifikasi & \multicolumn{2}{c}{ Jumlah } \\
\cline { 3 - 4 } & & f & $\%$ \\
\hline 1. & Mudah & 26 & 43,3 \\
\hline 2. & Cukup & 19 & 31,7 \\
\hline 3. & Sulit & & 15 & 25 \\
\hline & & Jumlah & 60 & 100 \\
\hline
\end{tabular}

Tabel 6, menunjukan masyarakat buruh sadap karet kurang dari setenganya mudah dalam mendapatkan pelayanan kesehatan yaitu sebanyak 43,3 \% sedangkan buruh sadap yang sulit mendapatkan fasilitas kesehatan sekitar 25\%.

Fasilitas kesehatan masyarakat merupakan suatu bentuk sarana pelayanan kesehatan yang digunakan untuk pencegahan dan penanganan penyakit. Seperti yang tertera pada Peraturan Presiden Republik Indonesia No.12 (2013) tentang jaminan kesehatan yang menjelaskan bahwa Fasilitas Kesehatan adalah fasilitas pelayanan kesehatan yang digunakan untuk menyelenggarakan upaya pelayanan kesehatan perorangan, baik promotif, preventif, kuratif maupun rehabilitatif yang dilakukan oleh pemerintah pusat, pemerintah daerah, dan/atau masyarakat. Fasilitas kesehatan yang diberikan PTPN VIII Wangunreja berupa balai pengobatan dan rumah sakit merupakan fasilitas kesehatan yang biasa digunakan oleh masyarakat buruh sadap karet untuk berobat. Dalam hal kemudahan mendapatkan fasilitas kesehatan, masyarakat buruh sadap karet ini sebagian besar merasa cukup mudah mendapatkannya fasilitas tersebut dan ada beberapa yang merasa 
kesulitan mendapatkan fasilitas kesehatan. Kesulitan mendapatkan fasilitas kesehatan yang dirasakan masyarakat buruh sadap karet ini lebih diakibatkan karena jarak yang jauh antara rumah buruh sadap karet ke rumah sakit.

Masyarakat buruh sadap karet sudah mempunyai kesadaran akan pentingnya pendidikan anak, walaupun sebagian dari anak mereka hanya menempuh pendidikan sampai Sekolah Menengah Pertama (SMP) tetapi sudah lebih tinggi dari pendidikan orangtuanya yang rata-rata hanya berpendidikan Sekolah Dasar. Untuk melihat kemudahan menyekolahkan anak yang meliputi jenjang pendidikan, biaya pendidikan dan jarak rumah ke sekolah dapat dilihat pada tabel 7 .

Tabel 7. Kemudahan Menyekolahkan Anak

\begin{tabular}{llccc}
\hline \multirow{2}{*}{ No. } & \multirow{2}{*}{ Klasifikasi } & \multicolumn{2}{c}{ Jumlah } \\
\cline { 3 - 5 } & & 41 & f \\
\hline 1. & Mudah & & 11 & 68,4 \\
\hline 2. & Cukup & & 8 & 18,3 \\
\hline 3. & Sulit & Jumlah & 60 & 13,3 \\
\hline & & & \\
\hline
\end{tabular}

Tabel 7, menunjukan bahwa lebih dari setengahnya masyarakat buruh sadap karet mudah dalam menyekolahkan anaknya yaitu $68,4 \%$. Sebagian kecil masyarakat buruh sadap karet ini merasa kesulitan untuk menyekolahkan anaknya sebanyak 13,3\%.

Pendidikan merupakan salah satu indikator dari tingkat kesejahteraan. Seperti yang dikatakan Mulyadi (2003) Pendidikan memberikan sumbangan langsung terhadap pertumbuhan pendapatan nasional melalui peningkatan keterampilan dan produktivitas kerja. Pendidikan berfungsi menyiapkan salah satu input dalam proses produksi, yaitu tenaga kerja, agar dapat bekerja dengan produktif karena kualitasnya. Selanjutnya akan mendorong peningkatan output yang diharapkan bermuara pada kesejahteraan. Masyarakat buruh sadap karet sadar akan pentingnya pendidikan untuk anak-anaknya di masa depan, hal tersebut terlihat dari tingkat pendidikan anak pada masyarakat buruh sadap karet setingkat lebih tinggi jika dibandingkan orang-tuanya. Dilihat dari kemudahan menyekolahkan anak ke jenjang pendidikan lebih tinggi, sebagian besar masyarakat buruh merasa mudah dalam menyekolahkan dan sebagian lagi merasa sulit karena keterbatasan biaya.

Fasilitas trasnportasi merupakan sarana yang digunakan buruh sadap karet untuk memudahkan aktivitas yang dilakukan sehari-hari. Selain fasilitas transportasi umum seperti angkutan umum dan ojeg, kepemilikan trasportasi pribadi menunjukkan adanya tingkat kesejahteraan baik.

Sebagain besar buruh sadap karet mementingkan sarana transportasi untuk mendukung aktivitas sehari-harinya, karena selain menyadap karet mereka memiliki aktivitas lain seperti ngojeg, bertani dan mencari rumput. Beberapa desa di Kecamatan Dawuan transportasi umum sangat langka dan sulit didapat karena aksesnya cukup sulit sehingga menuntut mereka untuk mempunyai kendaraan sendiri agar dapat membantu aktivitasnya.

Tabel 8. Kemudahan Mendapatkan Fasilitas Transportasi

\begin{tabular}{|c|c|c|c|}
\hline \multirow{2}{*}{ No. } & \multirow{2}{*}{ Klasifikasi } & \multicolumn{2}{|c|}{ Jumlah } \\
\hline & & $\mathrm{f}$ & $\%$ \\
\hline 1. & Mudah & 6 & 10 \\
\hline 2. & Cukup & 14 & 23,3 \\
\hline 3. & Sulit & 40 & 66,7 \\
\hline & Jumlah & 60 & 100 \\
\hline
\end{tabular}


Tabel 8 menunjukan bahwa masyarakat buruh sadap karet sebagian besar mengalami kesulitan dalam mendapatkan fasilitas transportasi yaitu sebanyak $66,7 \%$ dan sebagian kecil masyarakat buruh sadap merasa mudah mendapatkan fasilitas transportasi sebanyak $10 \%$. Kemudahan diartikan sebagai tersedianya fasilitas pelayanan (ekonomi dan sosial) sehingga masyarakat dapat memenuhi berbagai kebutuhan hidupnya. Seperti dijelaskan Adisasmita (2013), Tersedianya fasilitas mampu memberikan pelayan pemenuhan berbagai kebutuhan kepada masyarakat, berarti masyarakat merasa berkecukupan atau berkesejahteraan karena berbagai kebutuhan, keinginan dan kepentingan hidupnya dapat terpenuhi dengan cukup, mudah dan lancar. Transportasi memiliki peranan yang sangat penting bagi keberhasilan suatu pembangunan karena dengan perkembangan transportasi yang semakin pesat akan meningkatkan perekonomian daerah, secara tidak langsung akan berpengaruh terhadap tingkat kesejahteraan masyarakat setempat. Sebagian besar masyarakat buruh sadap karet PTPN VIII Wangunreja merasa kesulitan mendapatkan fasilitas transportasi pribadi karena tidak adanya biaya untuk membeli sarana transportasi, dan masyarakat buruh sadap karet yang merasakan kesulitan mendapatkan transportasi umum karena kondisi jalan yang rusak dan jarak yang jauh antara rumah ke jalan raya

Kesejahteraan merupakan tujuan hidup yang selalu diharapkan semua masyarakat. Perbedaan tingkat kesejahteraan tersebut diukur berdasarkan indikator dari Badan Pusat Statistika tahun 2005 yang meliputi pendapatan, pengeluaran rumah tangga, keadaan tempat tinggal, fasilitas tempat tinggal, kesehatan anggota keluarga, kemudahan mendapatkan fasilitas kesehatan, kemudahan menyekolahkan anak, dan kemudahan mendapatkan fasilitas kesehatan. Berdasarkan data yang diperoleh, dapat dilihat tingkat kesejahteraan masyarakat buruh sadap karet di Kecamatan Dawuan pada tabel 9 .

Tabel 9. Tingkat Kesejahteraan Buruh sadap Karet

\begin{tabular}{ccccc}
\hline No. & Kategori & Jumlah Skor & Jumlah Responden & $\%$ \\
\hline 1. & Tingkat Kesejahteraan Tinggi & $20-24$ & 4 & 6,7 \\
\hline 2. & Tingkat Kesejahteraan Sedang & $14-19$ & 47 & 78,3 \\
\hline 3. & Tingkat kesejahteraan Rendah & $8-13$ & 9 & 15 \\
\hline & Jumlah & & 60 & 100 \\
\hline
\end{tabular}

Suatu masyarakat dikatakan sejahtera apabila kebutuhan dasarnya dapat terpenuhi. Seperti yang dijelaskan Kementrian Koordinator Kesejahteraan Rakyat (dalam Rinawati, 2010) sejahtera yaitu suatu kondisi masyarakat yang terpenuhi kebutuhan dasarnya. Kebutuhan dasar tersebut berupa kecukupan mutu sandang, pangan, papan, kesehatan, pendidikan, lapangan pekerjaan, dan kebutuhan dasar lainnya. Seperti yang terlihat pada tabel 9 bahwa sebagian besar masyarakat buruh sadap karet di Kecamatan Dawuan termasuk ke dalam tingkat kesejahteraan sedang yaitu sebanyak $78,3 \%$, dan sebagian lagi termasuk ke dalam tingkat kesejahteran rendah dan tinggi.

\section{SIMPULAN}

Tingkat kesejahteraan buruh sadap karet PTPN VIII Wangunreja di Kecamatan Dawuan yang meliputi pendapatan, pengeluaran keluarga, keadaan tempat tinggal, fasilitas tempat tinggal, kesehatan anggota keluarga, kemudahan mendapatkan pelayanan kesehatan, kemudahan menyekolahkan anak, dan kemudahan mendapatkan fasilitas transportasi.

Pendapatan buruh sadap karet sebesar Rp.1.110.000, pendapatan tersebut tergolong rendah karena masih di bawah 
UMR Kota/ Kabupaten Subang yaitu Rp. 1.577.959, pendapatan yang diperoleh tersebut tidak cukup untuk memenuhi kebutuhan keluarga yang rata-rata terdiri dari 3 orang, sehingga mengharuskan para buruh sadap untuk melakukan pekerjaan sampingan serta mengajak anggota keluarga yang lain seperti anak dan istri untuk bekerja agar dapat memenuhi kebutuhan keluarga sehari-hari.

Rata-rata masyarakat buruh sadap karet ini memiliki pengeluaraan lebih dari Rp. 1.000.000. Pengeluaran terbesar yang di keluarkan para buruh sadap karet sebagian besar untuk kebutuhan makan keluarga. Jika dibandingkan dengan pendapatan, penge-luaran keluarga jauh lebih besar, oleh sebab itu para buruh sadap harus bisa mengelola keuangan dengan baik agar kebutuhan dasar keluarga dapat terpenuhi.

Keadaan tempat tinggal buruh sadap karet sebagian besar sudah permanen yaitu jenis rumah beratap genteng, berdinding tembok dan berlantai keramik. Sebagian kecilnya masyarakat ini tinggal di rumah semi permanen yaitu rumah dengan dinding setengah tembok dan setengahnya lagi papan dengan lantai dari semen. Keterbatasan biaya merupakan salah satu penyebab mereka memperbaiki keadaan tempat tinggalnya.

Fasilitas tempat tinggal buruh sadap karet lebih dari setengahnya kurang lengkap, kelengkapan fasilitas tersebut dilihat dari kepemilikan pekarangan dan kecukupan ruang. Sebagian dari buruh sadap karet tidak memiliki ruang yang cukup di dalam rumah dan setengahnya tidak memiliki pekarangan karena lahan yang mereka miliki terbatas, hanya cukup untuk membangun rumah.

Kesehatan anggota keluarga buruh sadap karet cukup bagus, hal tersebut dapat diketahui dari sebagian besar anggota keluarga buruh sadap karet tidak memiliki penyakit, namun kesadaran akan kesehatan masih terbilang rendah karena sebagian besar buruh sadap karet ini tidak pernah melakukan cek kesehatan.
Kemudahan mendapatkan fasilitas kesehatan pada masyarakat buruh sadap karet cukup beragam dari yang mudah, sedang sampai sulit. Kesulitan mendapatkan fasilitas kesehatan tersebut diakibatkan karena jarak tempuhnya yang jauh antara rumah buruh sadap karet ke sarana kesehatan.

Kemudahan menyekolahkan anak pada masyarakat dilihat dari jenjang pendidikan, biaya dan jarak rumah ke sekolah. Lebih dari setengahnya masyarakat buruh sadap karet mudah menyekolahkan anak, sedangkan sebagian kecilnya buruh sadap karet merasa kesulitan. Kesulitan tersebut diakibatkan karena tidak adanya biaya untuk melanjutkan pendidikan ke jenjang yang tinggi dan lebih memilih untuk bekerja agar dapat membantu perekonomian keluarga.

Kemudahan mendapatkan fasilitas transportasi pada buruh sadap karet ini lebih dari setengahnya merasa sulit dan sebagian lagi merasa mudah. Kesulitan mendapatkan fasilitas transportasi tersebut disebabkan aksesnya susah seperti jalannya yang rusak dan jauh dari jalan raya.

Berdasarkan hasil skoring dari delapan indikator kesejahteraan menurut BPS tahun 2005, sebagian besar tingkat kesejahteraan masyarakat buruh sadap karet PTPN VIII Wangunreja di Kecamatan Dawuan termasuk ke dalam tingkat kesejahteraan sedang sebanyak 78,3\% dan sebagian lagi termasuk ke dalam tingkat kesejahteraan rendah sebanyak $15 \%$ serta tingkat kesejahteraan tinggi 6,7\%.

Adapun saran penelitian yang dapat direkomendasikan sebagai berikut: 1) Pihak PTPN VIII Wangunreja agar memberikan upah kepada masyarakat buruh sadap karet sesuai UMR Kota/ Kabupaten Subang, sehingga dapat buruh sadap karet mampu memenuhi kebutuhan keluarganya; 2) Bagi masyarakat buruh sadap karet agar memiliki usaha sampingan untuk memperoleh penghasilan tambahan selain dari hasil menyadap seperti berjualan bahan pokok makanan, 
karena sangat sulit ditemui warung dan akses ke pasar cukup sulit; 3) Untuk indikator yang masih rendah seperti pendapatan, fasilitas tempat tinggal, dan kemudahan mendapatkan fasilitas transportasi agar ada upaya peningkatan; 4) Untuk indikator yang sudah bagus seperti keadaan tempat tinggal, kesehatan anggota keluarga, kemudahan mendapatkan fasilitas kesehatan, dan kemudahan menyekolahkan anak agar di pertahankan dan ditingkatkan; 5) Untuk peneliti selanjutnya hendaknya melakukan penelitian tentang hubungan kontribusi setiap indikator kesejahteraan dengan tingkat kesejahteraan buruh sadap karet PTPN VIII Wangunreja di Kabupaten Subang, serta dapat menjadi bahan masukan dalam rangka melengkapi penelitian selanjutnya.

\section{DAFTAR PUSTAKA}

Adisasmita, Rahardjo. (2013). Teori-teori Pembangunna Ekonomi (Pertumbuhan Ekonomi dan Pertumbuhan Wilayah). Yogyakarta: Graha Ilmu.

Badan Pusat Statistik. (2005). Indikator Kesejahteraan Rakyat. Jakarta: BPS
Mulyadi. S. (2003). Ekonomi Sumber Daya manusia (Dalam Perspektif Pembangunan). Jakarta: PT RajaGrafindo Persada.

Peraturan Menteri PU No. 54. Tahun 1991. Tentang Pedoman Teknis Pembangunan Perumahan Sangat Sederhana.

Peraturan Presiden Republik Indonesia No. 12 Tahun 2013. Tentang Jaminan Kesehatan. Jakarta

Rinawati. (2010). Tingkat kesejahteraan Masyarakat Nelayan di Kecamatan Losari Kabupaten Cirebon. Skripsi. Bandung: FPIPS UPI.

Sastraatmadja, Entang. (1984). Ekonomi Pertanian Indonesia. Bandung: Angkasa.

Soetrisno, Loekman. (2002). Paradigma Baru Pembangunan Pertanian Sebuah Tinjauan Sosiologis. Yogyakarta: Kanisius

Sukirno, Sadono. (2004). Makro Ekonomi Teori Pengantar. Jakarta: PT Raja Grafindo Perkasa.

Undang-Undang RI No. 12011 Tentang Perumahan Dan Kawasan Permukiman. Jakarta

Undang-Undang RI No. 18 Tahun 2004. Tentang Perkebunan. Yogyakarta: Aditya Media. 